Language Acquisition and Change 



\section{Language Acquisition and Change}

A Morphosyntactic Perspective

Jürgen M. Meisel, Martin Elsig and Esther Rinke 
(C) Jürgen M. Meisel, Martin Elsig and Esther Rinke, 20I3

Edinburgh University Press Ltd

22 George Square, Edinburgh EH8 $9 \mathrm{LF}$

www.euppublishing.com

Typeset in I I.5/ I3 Ehrhardt by

Servis Filmsetting Ltd, Stockport, Cheshire, and printed and bound in Great Britain by CPI Group (UK) Ltd, Croydon CRo 4 YY

A CIP record for this book is available from the British Library

ISBN 978 o 74864225 o (hardback)

ISBN 978 o 748677993 (webready PDF)

ISBN 978 o 748678 o I 3 (epub)

The right of Jürgen M. Meisel, Martin Elsig and Esther Rinke to be identified as author of this work

has been asserted in accordance with

the Copyright, Designs and Patents Act 1988. 